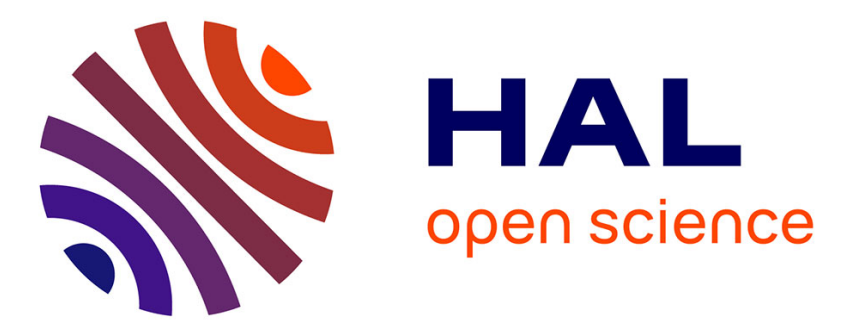

\title{
Non-destructive biomass estimation of herbaceous plant individuals: A transferable method between contrasted environments
}

Julien Pottier, Franck Jabot

\section{- To cite this version:}

Julien Pottier, Franck Jabot. Non-destructive biomass estimation of herbaceous plant individuals: A transferable method between contrasted environments. Ecological Indicators, 2017, 72, pp.769 - 776. 10.1016/j.ecolind.2016.08.030 . hal-01521547

\section{HAL Id: hal-01521547 \\ https://hal.science/hal-01521547}

Submitted on 16 May 2020

HAL is a multi-disciplinary open access archive for the deposit and dissemination of scientific research documents, whether they are published or not. The documents may come from teaching and research institutions in France or abroad, or from public or private research centers.
L'archive ouverte pluridisciplinaire HAL, est destinée au dépôt et à la diffusion de documents scientifiques de niveau recherche, publiés ou non, émanant des établissements d'enseignement et de recherche français ou étrangers, des laboratoires publics ou privés.

\section{다(1)(2)}

Distributed under a Creative Commons Attribution - ShareAlikel 4.0 International 
1 Title : Non-destructive biomass estimation of herbaceous plant individuals: a

2 transferable method between contrasted environments.

3

4 Author list: Julien Pottier and Franck Jabot

$5 \quad$ Pottier, J. (Corresponding author, julien.pottier@ clermont.inra.fr) ${ }^{1}$

$6 \quad$ Jabot, F. (franck.jabot@irstea.fr) ${ }^{2}$

$7 \quad{ }^{1}$ INRA, UR874 (Unité de Recherche sur l'Ecosystème Prairial), 5 chemin de Beaulieu, F-

863039 Clermont-Ferrand, France.

$9 \quad{ }^{2}$ Irstea, UR LISC, Centre de Clermont-Ferrand, F-63178 Aubiere, France. 


\section{Abstract}

Monitoring plant growth at the individual level in arrays of environmental conditions is key to understanding plant functioning with strong implications for ecophysiology, population biology and community ecology. This requires non-destructive methods for repeated estimates of individual plant biomass in time. Although allometric equations have been widely used for trees and shrubs, there is currently no general approach for herbaceous species that can be applied across habitats, plant architecture, life stage and leading to transferable equations between contrasted environments. Here we propose a method based on three biometric measurements of the minimum volume occupied by aboveground plant organs. A total of 36 equations were fitted and compared for twelve species of temperate grasslands, corresponding to various volume shapes, scaling functions (linear or power) and including (or not) a life stage effect. The accuracy of the selected equations was compared to similar attempts reported in the literature. We further assessed the across-site transferability of the best allometric equations. The goodness-of-fit of the best equations selected for each species was high ( $\bar{R}^{2}=0.83$ ). The type of selected equations was species-specific, emphasising the benefits of considering a wide range of plant volume shapes and both linear and power functions. Using a comprehensive assessment of allometric equation transferability, we found that site effects could be neglected for eleven out of twelve species. Biomass equations based on the minimum volume proved accurate. The proposed method is easy to implement in any type of habitat, copes with various plant architectures and reduces risks of error measurement compared to previously developed approaches. The method further allows, for the first time, to use a single equation for monitoring the growth trajectory of herbaceous plant individuals in contrasted environments.

Keywords: Grasslands; allometry; canopy volume; individual-based monitoring; plant biomass; growth trajectory. 


\section{Introduction}

Monitoring plant growth in arrays of environmental conditions is critical for understanding plant functioning with strong implications for ecophysiology, population biology and community ecology. Tree growth monitoring is naturally performed at the individual level (Peacock et al. 2007), and refined allometric models have been developed to deduce tree and shrub biomass from non-destructive biometric measurements (Henry et al. 2013; Chave et al. 2014; Zhang et al. 2016). In contrast, the growth monitoring of herbaceous plants has been mostly performed at the population (Hooper et al. 2005) or community levels (Sala et al. 1988). Consequently, non-destructive methods of herbaceous plant biomass estimation have been mainly developed at these organization levels (Catchpole \& Wheelert 1992; Harmoney et al. 1997; Brathen \& Hagberg 2004; Barkaoui et al. 2013).

This focus of plant ecologists on population and community levels for herbaceous plants can be explained by the huge number of herbaceous individuals, even in small-sized monitoring plots, and by the uncertainty surrounding the definition of herbaceous individuals due to the varying levels of physiological integration between plant ramets (Harper 1977). Still, clearer understanding of herbaceous plant demographical processes requires conducting studies at the individual level because plant responses to abiotic factors and plant-plant interactions are processes operating at the level of plant individuals (Damgaard et al. 2002; Purves \& Law 2002; Kraft et al. 2015).

The dynamics of individual plant biomass has traditionally been assessed through destructive sampling of replicates (e.g. Shipley \& Meziane 2002). This approach has several drawbacks. First, it is time consuming and costly, which represents a strong limitation for collecting data of suitable frequency and/or number of replicates. Second, and most importantly, such a destructive method does not allow the monitoring of growth trajectories of single individuals 
but rather average trajectories of populations of individuals. Non-destructive methods are therefore required for repeated estimates of individual plant biomass in time.

A review of the literature (appendix A, see methods) reveals 15 studies that have developed non-destructive methods for individual herbs. These studies generally rely on the use of allometric equations relating various biometric plant measures to individual biomass (but see Tackenberg 2007). The most widely used biometric measure is plant height (e.g. Guevara et al. 2002), but other measures have also been used in isolation or in combination with plant height, including plant cover (Röttgermann et al. 2000), basal area (Guevara et al. 2002), canopy width (Assaeed 1997), or various volume formulations (Johnson et al. 1988; Damgaard et al. 2002). These studies report overall good fits of allometric equations $\left(R^{2}=\right.$ $0.82 \pm 0.12$ ). However, the universality of this approach remains to be evaluated for herbaceous species since i) mostly (semi-)arid or artificial systems (i.e. pot experiments like Damgaard et al. 2002) have been considered in which plant individuals are strongly spatially segregated; ii) the dependence of allometric relationships on environmental conditions and plant life stages have not been thoroughly investigated, so that the transferability of calibrated allometric equations across study sites is to be demonstrated and iii) the influence of plant architecture on the usefulness of the different biometric measures remains poorly documented.

Here, we calibrate a set of allometric equations for estimating the biomass of individual plants for twelve typical species of temperate grasslands of various architectural types and sizes. Our primary objective is to compare alternative allometric equations regarding their across sites transferability. We also compare the gain in accuracy associated with the use of three biometric measurements (instead of simply one or two), and with the inclusion of phenological stage and site effects in the allometric equations. To do so, a set of allometric equations were calibrated using destructive samples collected in contrasted environments. 
Before destruction the samples were first measured according to three biometric

measurements: plant height, basal and mid-height circumferences (Fig. 1). Based on the reported results, we provide some guidelines for optimising the predictive accuracy and transferability of the proposed non-destructive method of biomass estimation of herbaceous plant individuals.

A) Apparent volume

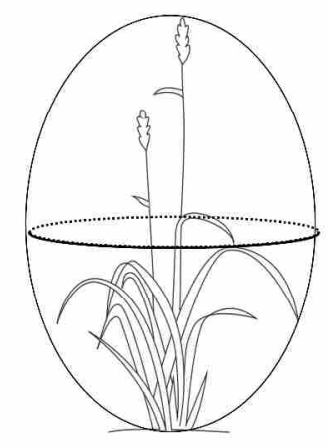

B) Minimum volume

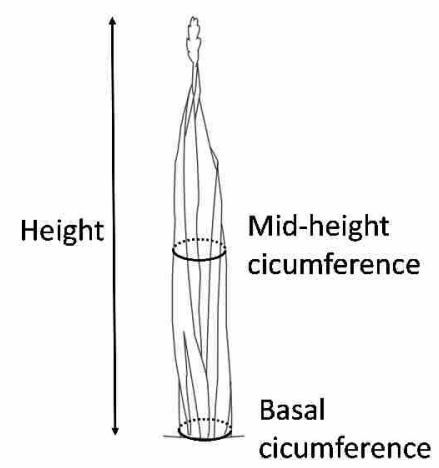

Figure 1 The biometric measurements being considered. The apparent volume (left panel) is difficult to estimate accurately because the spatial arrangement of organs of herbaceous species, especially leaves, strongly depends on external factors. The minimum volume (right panel) corresponds to the volume that an individual plant occupies when all aboveground organs are joined together and uncoiled along the plant longitudinal axis. We consider height, basal circumference and circumference at mid height to estimate the minimum volume (see Table 3 for formulations).

\section{Material and Methods}

\subsection{Literature review}

A search was conducted in ISI ${ }^{\circ}$ Web of Science with the timespan 1950 to 2015 using the keywords "non-destructive" AND “biomass" AND “plants”. This resulted in 430 references. 
Articles focusing on trees, shrubs and aquatic species were excluded. Finally, we considered only the minority of studies, and associated references, estimating biomass of plant individuals and not stand or population levels in open habitats. This evaluation resulted in a set of 15 references reporting allometric equations for a total of 76 species. These studies were either located in arid habitats or were pot experiments (Appendix A).

\subsection{Site and species characteristics}

We selected twelve species that are typical of temperate grasslands of Western Europe: six grass species (Dactylis glomerata, Arrhenaterum elatius, Poa pratensis, Agrostis capillaris, Elymus repens, Lolium perenne), four forbs (Plantago lanceolata, Taraxacum officinale, Achillea millefolium, Veronica chamaedrys) and two legumes (Trifolium pratensis, Lotus corniculatus). The selection of species was based on their plant traits and aimed at testing our method over a large variety of plant growth strategy and morphology (Table 1). We thus considered fast growing exploitative species like Arrhenatherum elatius, slower growing and more conservative species like Achillea millefolium and species of various canopy architecture and size. Indeed, we sampled all shoot growth forms, types of leaf distribution, and a large proportion of the plant height distribution referenced in the LEDA trait database for herbaceous plants (Kleyer et al. 2008; Appendix B).

\begin{tabular}{|c|c|c|c|c|c|c|}
\hline Species & $\begin{array}{c}\begin{array}{c}\text { Height } \\
(\mathrm{mm})\end{array} \\
\end{array}$ & $\begin{array}{l}\text { LDMC } \\
(\mathrm{mg} / \mathrm{g}) \\
\end{array}$ & $\begin{array}{c}\text { SLA } \\
\left(\mathrm{mm}^{2} / \mathrm{mg}\right) \\
\end{array}$ & SeedMass (mg) & Leaf distribution & Shoot growth form \\
\hline Achillea millefolium & 472 & 194.4 & 12.02 & 0.132 & Semi-rosette & Stem erect \\
\hline Agrostis capillaris & 669 & 266.3 & 31.28 & 0.064 & Regular distribution along the stem & Stem ascending to prostrate \\
\hline Arrhenatherum elatius & 1177 & 255.1 & 29.18 & 3.079 & Semi-rosette & Stem erect \\
\hline Dactylis glomerata & 1075 & 258.8 & 22.80 & 0.911 & Regular distribution along the stem & Stem erect \\
\hline Elymus repens & 746 & 273.5 & 25.08 & 2.375 & Regular distribution along the stem & Stem erect \\
\hline Lolium perenne & 801 & 207.7 & 24.68 & 1.975 & Semi-rosette & Stem erect \\
\hline Lotus corniculatus & 286 & 206.0 & 27.67 & 1.403 & Regular distribution along the stem & Stem ascending to prostrate \\
\hline Plantago lanceolata & 567 & 181.5 & 17.32 & 1.617 & Rosette & Stem erect \\
\hline Poa pratensis & 608 & 288.0 & 16.25 & 0.273 & Semi-rosette & Stem ascending to prostrate \\
\hline Taraxacum officinale & 489 & 159.7 & 23.40 & 0.532 & Rosette & Stem erect \\
\hline Trifolium pratense & 667 & 205.0 & 23.33 & 1.581 & Regular distribution along the stem & Stem erect \\
\hline Veronica chamaedrys & 250 & 312.1 & 20.39 & 0.206 & Regular distribution along the stem & Stem ascending to prostrate \\
\hline
\end{tabular}


124 Table 1. Study species characteristics. Trait values are extracted from the LEDA trait

125 database (Kleyer et al. 2008).

126 We aimed at calibrating allometric equations that would hold for an array of environments,

127 plant size and phenological stages. To do so, we applied a double sampling procedure on plant

128 individuals collected in contrasted habitats. This procedure involved measuring and

129 harvesting ten individuals in four different sites for each of the twelve species studied

130 (resulting in a total of 40 individuals per species). We selected plants covering a wide range of

131 plant sizes and phenological stages. Since all species were not present at each site, we

132 collected data in a total of 15 sites located in the Sancy massif in Central France with

133 contrasted characteristics in terms of altitude, climate, topography, soil type and agricultural

134 use (Table 2). Field sampling was performed from early June to late July 2015 (Appendix C).

135 Sampling ten individuals of twelve species in four sites resulted in biometric measurements,

136 harvesting and weighing of 480 individual plants.

137 


\begin{tabular}{lccccc}
\hline Sites & $\begin{array}{c}\text { Elevation } \\
(\mathrm{m} \text { a.s.l) }\end{array}$ & $\begin{array}{c}\text { Sum DDEG5 } \\
\left({ }^{\circ} \mathrm{C}\right)\end{array}$ & $\begin{array}{c}\text { Annual } \\
\text { precipitation } \\
(\mathrm{mm})\end{array}$ & Parent material & $\begin{array}{c}\text { Agricultural } \\
\text { use }\end{array}$ \\
\hline $\mathrm{A}$ & 1358 & 942 & 1000 & Volcanic & Grazed \\
$\mathrm{B}$ & 1254 & 1051 & 964 & Volcanic & Abandonned \\
$\mathrm{C}$ & 1454 & 840 & 1038 & Volcanic & Mown \\
$\mathrm{D}$ & 1384 & 915 & 1012 & Plutonic & Grazed \\
$\mathrm{E}$ & 1179 & 1134 & 934 & Volcanic & Abandonned \\
$\mathrm{F}$ & 1088 & 1250 & 890 & Volcanic & Mown \\
$\mathrm{G}$ & 1056 & 1283 & 881 & Volcanic & Grazed \\
$\mathrm{H}$ & 1000 & 1350 & 859 & Volcanic & Mown \\
$\mathrm{I}$ & 1059 & 1279 & 880 & Volcanic & Mown \\
$\mathrm{J}$ & 858 & 1552 & 791 & Volcanic & Grazed \\
$\mathrm{K}$ & 629 & 1894 & 700 & Marl & Mown \\
$\mathrm{L}$ & 730 & 1720 & 749 & Basalt & Grazed \\
$\mathrm{M}$ & 765 & 1668 & 763 & Basalt & Grazed \\
$\mathrm{N}$ & 606 & 1929 & 691 & Marl & Mown \\
$\mathrm{O}$ & 389 & 2247 & 625 & Marly limestone & Mown \\
\hline
\end{tabular}

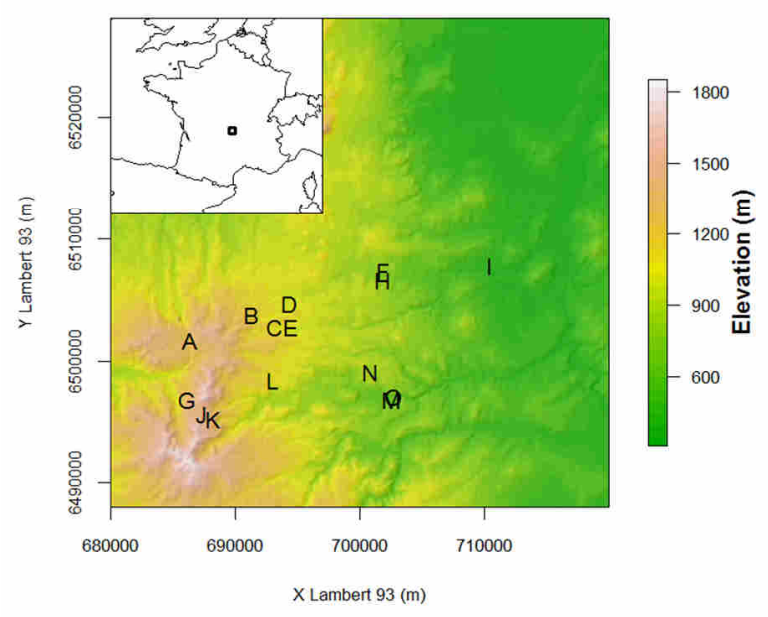

139 Table 2. Site characteristics and locations. Temperature and precipitation are derived from

$140100 \mathrm{~m}$ raster maps downscaled from the $1 \mathrm{~km}$ Worldclim grids (Hijmans et al 2005) following

141 the procedure of Dullinger et al (2012). DDEG5 stands for the annual sum of degree days

142 above $5{ }^{\circ}$ C. Soil data are derived from the European Soil Data Base V2.0 (2004).

143 Agricultural use is deduced from field observations.

In this study, we define an individual plant as a ramet or collection of clumped ramets with

147 the highest degree of physiological integration. Following this definition, an individual of a grass species may be represented by a single tiller or several adjacent and physiologically 
integrated tillers forming a tussock. The mass $B$ of a plant individual can be estimated from its volume $V$ following $B=V \times D$ where $D$ is the bulk density. The apparent volume of a plant is a combination of plant tissue and void. Bulk density is therefore a complex quantity that depends both on tissue characteristics and plant architecture (Figure 1-A). The void component of the plant apparent volume is an important source of inter-individual variability in estimated biomass. The spatial arrangement of leaves, stems and reproductive organs is highly dependent on external factors such as wind and neighbouring plants because of tissue flexibility. This makes any measurement of the apparent volume highly uncertain. Previous studies using measures of a plant apparent volume have mostly been located in arid habitats where plants are spatially segregated, thereby decreasing this nuisance variability (see e.g. Johnson et al. 1988). To avoid difficulties of intertwined plants in the field, we consider the minimum volume of the canopy, rather than its apparent volume (Figure 1-B). We define the minimum volume as the volume that an individual plant occupies when all aboveground organs are joined together and uncoiled along the plant longitudinal axis. This requires hand manipulation of plants but does not alter their tissues nor their future growth.

We considered three simple biometric measurements to estimate the minimum volume of each plant: the maximum height, the basal circumference and the circumference at mid height (Figure 1-B). Both circumferences were measured with a graduated tape by tightening organs until first signs of resistance in order to avoid plant tissue damages. This procedure minimizes measurement error by reducing inter-individual variations in standing volume linked to neighbourhood conditions (Fig. 1). Furthermore, there is very little potential variation in circumference measurement linked to the tightening force exerted by the observer, since large tightening forces are avoided to preserve the plant from tissue damage. These biometric measurements were recorded in the field for the 480 plant individuals considered. The plants were then clipped to ground level. In the lab, we sorted dead material, 
green tissues and reproductive organs. All plant samples were oven-dried at $60^{\circ} \mathrm{C}$ during 48 hours and weighed. The total plant biomass including dead material was used for subsequent analyses.

Based on the three basic measurements introduced above, we formulated allometric equations for nine possible shapes of the minimum volume (Table 3). Shapes like cylinder, double cylinder, cone, double cone or ellipsoid were first considered as having a unique value of bulk density. We further considered the possibility that the lower and upper parts of shapes like double cylinder and double cone may show different bulk density. This was justified by the uneven distribution of different organs (leaves, stems, reproductive organs) along the longitudinal axis of plants. Finally, we also considered basic allometric models where the plant biomass is a simple function of height (stick) or height and basal circumference (reversed nail) or height and circumference at mid-height (spinning-top). We considered both linear and power relationships between the measured plant biomass and the patterns presented above. Both types of relationship correspond to two distinct hypotheses. The linear model assumes that the bulk density of plant individuals does not vary with plant size. Conversely, the power model assumes bulk density to vary with plant size as a result of non-isometric allocation between organs of different density during plant ontogeny (Weiner 2004; Poorter et al. 2015). 


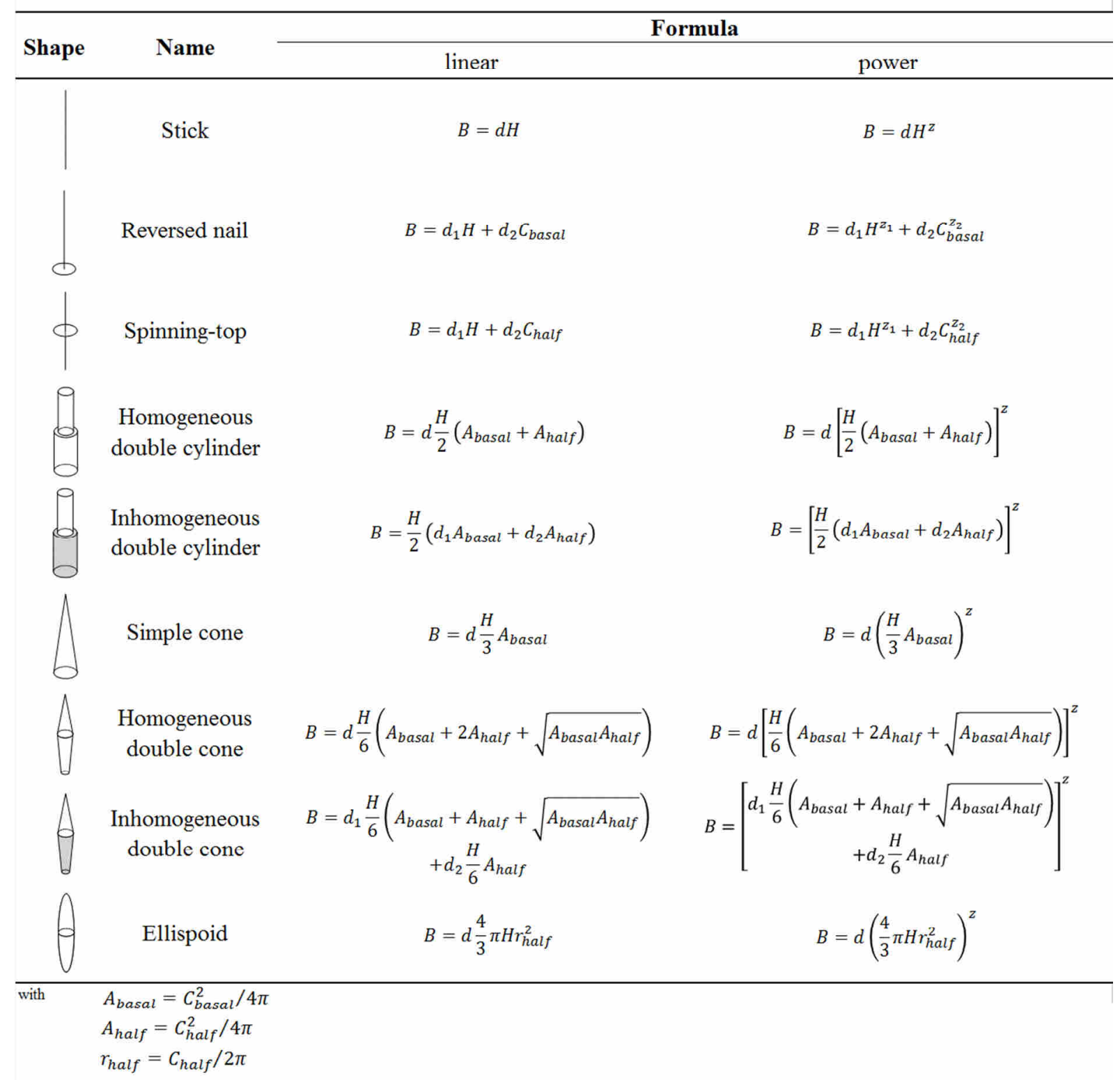

Table 3. Allometric equations based on various volume shapes. These equations make use of a plant's maximum height $(H)$, basal circumference $\left(C_{\text {basal }}\right)$ and circumference at mid-height $\left(C_{\text {half }}\right) . B$ indicates total dry biomass of aboveground organs. Volumes with both white and gray parts indicate that two different bulk densities $(d)$ are estimated.

Eighteen allometric models were initially tested for each species (i.e. total plant biomass regressed against nine patterns following either a linear or power function). We further tested the robustness of these allometric equations against environmental or life stage effects. To do so, we fitted 36 additional models where life stage or life stage and site were added as 
independent variables. Sites were considered as factors with four levels. Plant developmental stage was considered as a binary factor representing the presence or absence of reproductive organs. We assessed model performance following three criteria. First, we quantified the model goodness-of-fit to the full dataset ( $n=40$ for each species) using the coefficient of determination. Second, we computed model predictive accuracy using a repeated split-sample procedure (100 iterations). Seventy five per cent of the full dataset were used for model calibration $(\mathrm{n}=30)$ and $25 \%$ for model evaluation. The splitting procedure aimed at uniformly sample evaluation data within the range of species total biomass. We then calculated the average Normalized Root Mean Square Error of predictions (NRMSE) across the 100 iterations. Third, we assessed the across-site transferability using a 4-fold crossvalidation procedure where sites were used for data splitting. Therefore, the models were calibrated for all but one site $(n=30)$ and evaluated on the remaining site. We then calculated the average Normalized Root Mean Square Error of predictions (NRMSE) across the 4 possible iterations (one per site).

We compared the 54 models based on these three criteria (i.e. goodness-of-fit, predictive accuracy and between-site transferability), but selected the best equation for each species as the one showing the best between-site transferability.

All statistical analyses were performed under the R environment (R Core Team 2015). Scripts and basic data are provided in Appendices C-D.

\section{Results}

Among the 54 allometric equations, the most transferable one was selected for each of the 12 investigated species. The normalized errors reported for model transferability ranged between 0.11 and 0.35 with $\overline{N R M S E_{\text {transf }}}=0.20$ (Table 4). Differences in predictive accuracy between the most accurate and the selected models were low ( $\triangle$ NRMSE ranging between 0 
and 0.09), meaning that most transferable models were also the most accurate or close to the most accurate (Table 4). Overall, the selected equations showed high goodness-of-fit with $R^{2}$ ranging from 0.63 to 0.95 and $\bar{R}^{2}=0.83$ (Figure 2) and good predictive accuracy with NRMSE ranging from 0.10 to 0.23 and $\overline{N R M S E}=0.16$ (Table 4). These good performances are in line with the results retrieved from the few previous studies having documented allometric equations for herbaceous species in open habitats (Figure 2). Goodness-of-fit and predictive accuracy did not differ between plant functional groups and was not significantly correlated with the plant traits considered here (Table 1).

The selected model was very variable among species in terms of shape, type of function and importance of stage effect. The shapes of the selected models had non-evident relationships with species traits. Reversed nail was selected as the best shape for Trifolium pratensis only, simple cone for Plantago lanceolata, spinning-top for three species (Achillea millefolium, Elymus repens, Lotus corniculatus and Veronica chamaedrys), homogenous double cone for Poa pratensis, homogeneous double cylinder for three species (Agrostis capillaris, Lolium perenne and Taraxacum officinale), homogeneous ellipsoid for Arrhenatherum elatius, and inhomogeneous double cylinder for Dactylis glomerata. 


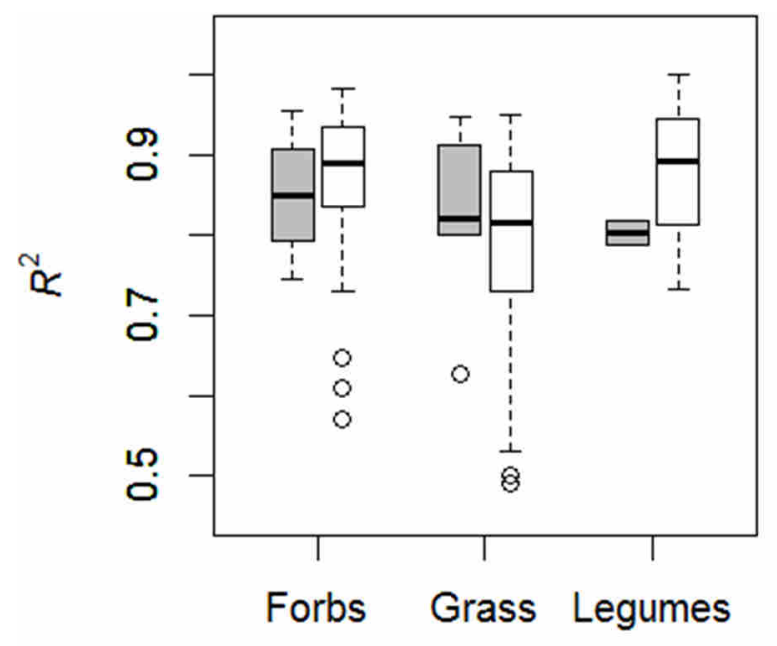

Figure 2. Goodness-of-fit of the allometric equation selected for each species from this study (gray boxes) and results extracted from the literature (white boxes; Appendix A).

The stick model based solely on plant height was never selected as the most transferable model (Table 4, Figure 3-A). It was further found to be the worst model for all species except Veronica chamaedrys. Shapes relying on basal circumference and height (reversed nail and simple cone) were selected for two out of twelve species. Shapes further including mid-height circumference were selected for the ten remaining species. The improvement in goodness-offit provided by this third biometric measure ranged between 0 and $18 \%$ (Figure $3-\mathrm{B}$ ). These results highlight that the complementary biometric measurements proposed in this study make a critical contribution to the predictive ability of the allometric equations.

Models including life stage effects were selected for seven out of twelve species (Figure 3-C). Although inclusion of life stage resulted in strong improvement for linear models (increase in $R^{2}$ up to $40 \%$ ), it did not improve power models by more than $7.2 \%$ except for Lolium perenne, which showed an increase of $17 \%$. Power functions were selected for seven out of 
twelve species. These results highlight that power functions are useful, but not essential, for predicting the biomass of temperate individual herbs at various stages of their life cycle.

Finally, we calibrated allometric equations including site effects. Although one may expect elevation to show a unidirectional influence, we did not find a clear pattern of site effects among the twelve species (Appendix E). We further assessed the gain in goodness-of-fit associated with the use of a site effect in the allometric equation, and found that this gain was limited for all species except Lolium perenne (Figure 3-D). For this peculiar species our results encourage to devise site specific allometric equations to recover a good predictive accuracy.
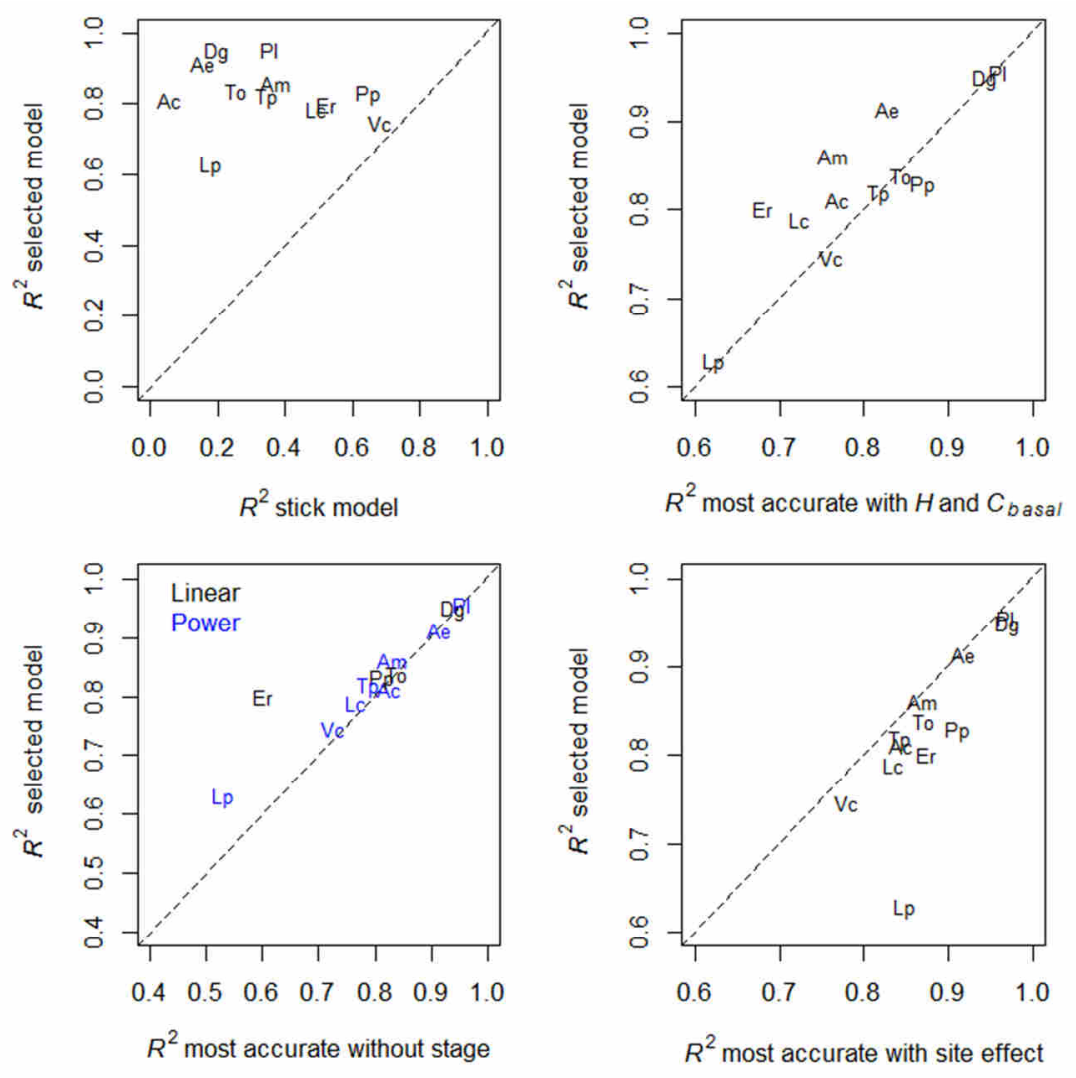

Figure 3. Goodness-of-fit of the selected models compared to A) the most accurate stick model without site effect, B) the most accurate model that relies on plant height $(H)$ and basal circumference $\left(C_{\text {basal }}\right)$ without site effect, $\left.C\right)$ the most accurate model without stage effect and D) the most accurate model including site effects. Letters indicate the species : Am (Achillea 
274 millefolium); Ac (Agrostis capillaris); Ae (Arrhenaterum elatius); Dg (Dactylis glomerata);

275 Er (Elymus repens); Lp (Lolium perenne); Lc (Lotus corniculatus); Pl (Plantago lanceolata);

276 Pp (Poa pratensis); To (Taraxacum officinale); Tp (Trifolium pratensis); Vc (Veronica

277 chamaedrys).

278

279 


\begin{tabular}{|c|c|c|c|c|c|c|c|c|c|c|c|c|c|c|}
\hline \multirow[b]{2}{*}{ Species } & \multirow[b]{2}{*}{ Shape } & \multirow[b]{2}{*}{ Function } & \multirow[b]{2}{*}{ Stage } & \multicolumn{7}{|c|}{ Fit with full dataset } & \multirow[b]{2}{*}{$\Delta R^{2}$} & \multicolumn{2}{|c|}{ Predictive accuracy } & \multirow{2}{*}{$\begin{array}{c}\begin{array}{c}\text { Between site } \\
\text { Transferability }\end{array} \\
\text { NRMSE }_{\text {transf }}\end{array}$} \\
\hline & & & & $R^{2}$ & $d$ & $d_{1}$ & $d_{2}$ & $z$ & $z_{1}$ & $z_{2}$ & & NRMSE & $\Delta$ NRMSE & \\
\hline Achillea millefolium & Spinning top & Power & yes & 0.86 & - & $2 \mathrm{E}-08$ & 0.75 & - & 4.06 & 2.26 & 0.008 & 0.15 & 0 & 0.15 \\
\hline Agrostis capillaris & $\begin{array}{l}\text { Homogeneous } \\
\text { double cylinder }\end{array}$ & Power & no & 0.81 & 5.95 & - & - & 0.53 & - & - & 0.029 & 0.16 & -0.012 & 0.24 \\
\hline Arrhenaterum elatius & $\begin{array}{l}\text { Homogenous } \\
\text { ellipsoid }\end{array}$ & Power & no & 0.91 & 2.27 & - & - & 0.76 & - & - & 0.004 & 0.1 & 0 & 0.14 \\
\hline Dactylis glomerata & $\begin{array}{l}\text { Inhomogeneous } \\
\text { double cylinder }\end{array}$ & Power & no & 0.95 & - & 0.03 & 0.16 & 0.92 & - & - & 0.021 & 0.12 & -0.035 & 0.15 \\
\hline Elymus repens & Spinning top & Linear & yes & 0.8 & - & 1.96 & 230.64 & - & - & - & 0.074 & 0.17 & -0.027 & 0.17 \\
\hline Lolium perenne & $\begin{array}{l}\text { Homogeneous } \\
\text { double cylinder }\end{array}$ & Power & yes & 0.63 & 0.44 & - & - & 0.81 & - & - & 0.176 & 0.23 & -0.094 & 0.35 \\
\hline Lotus corniculatus & Spinning top & Linear & yes & 0.79 & - & 1.31 & 31.20 & - & - & - & 0.070 & 0.18 & -0.019 & 0.30 \\
\hline Plantago lanceolata & Simple cone & Power & no & 0.96 & 2.85 & - & - & 0.72 & - & - & 0.006 & 0.1 & -0.011 & 0.11 \\
\hline Poa pratensis & $\begin{array}{l}\text { Homogeneous } \\
\text { double cone }\end{array}$ & Linear & yes & 0.83 & 0.11 & - & - & - & - & - & 0.035 & 0.18 & -0.035 & 0.29 \\
\hline Taraxacum officinale & $\begin{array}{l}\text { Homogeneous } \\
\text { double cylinder }\end{array}$ & Linear & no & 0.84 & 0.03 & - & - & - & - & - & 0.040 & 0.16 & -0.004 & 0.17 \\
\hline Trifolium pratensis & Reversed nail & Linear & yes & 0.82 & - & 5.3 & 60.17 & - & - & - & 0.025 & 0.15 & 0 & 0.17 \\
\hline Veronica chamaedrys & Spinning top & Power & yes & 0.75 & - & 0.03 & $3 \mathrm{E}-07$ & - & 1.55 & 13.4 & 0.007 & 0.19 & -0.017 & 0.20 \\
\hline
\end{tabular}

280 Table 4. Selected allometric equations for each species. The selection procedure is based on the lowest Normalized Root Mean Square Error of

281 the between-site transferability analysis $\left(\mathrm{NRMSE}_{\text {transf }}\right)$ among models that do not account for potential site effects. The selected models were 


\section{Discussion}

285

286

287

The method proposed here is accurate, easy to implement and leads to equations that are generally transferable between contrasted environments. The selected allometric equations for each species showed high prediction accuracy and goodness of fit, similar to the results reported in the literature (Appendix A). The main difference is that our method relies on the minimum volume whereas other studies have used the apparent volume (e.g. Johnson et al. 1988, see Appendix A). The apparent volume can be easily estimated in systems where plants are spatially segregated such as in arid habitats where all previous studies have been conducted. However, in intricate vegetation, such as in temperate grasslands, the plant canopy cannot clearly be delineated at the individual level. We here demonstrated that biomass estimations based on the minimum volume efficiently circumvent this problem, making the proposed method relevant to any herbaceous community.

Results from the present study show that the three investigated biometric measurements (height, basal circumference and mid-height circumference) are complementary (Fig. 3A-B). They allow to select for the best shape among nine possible formulation of the minimum volume. Our investigation was based on a modest number of species but covered a large range of canopy architecture, size and leaf traits of the Western European flora. Six out of nine shapes, which made use of two to three biometric measurements were selected as the best formulations (Table 4). These results provide evidence of the flexibility of the method, which can cope with different plant architectures and grassland types.

In the present work, power functions often resulted in greater predictive power than linear functions, indicating significant variations of plant bulk density with plant size. This is consistent with the fact that power models without and with reproductive stage as independent predictor showed similar goodness-of-fit whereas linear models without stage effect were generally less accurate than models including stage effect. This can be interpreted as a 
consequence of allometric biomass allocation between stems, leaves and reproductive organs during plant ontogeny that do not have the same bulk densities (Niklas 2004; Weiner 2004; Poorter et al. 2015). Although the power function is biologically justified by the allometric scaling theory, it was not always associated with significant fit improvements in our study. Four out of twelve studied species exhibited linear relationships and several studies reported good estimations of individual herb biomass from linear models (Gutierrez \& Aguilera 1989; Assaeed 1997; Röttgermann et al. 2000; Guevara et al. 2002; Hirata et al. 2007; van der Eynden 2011). Isometric scaling between plant organs has been reported for small plants (Enquist \& Niklas 2002; Enquist et al. 2007; Poorter et al. 2015), and is consistent with optimal biomass partitioning theory (Lohier et al. 2014). Our contrasted findings emphasize the need to systematically consider linear and non-linear functions when fitting biomass equations from biometric measurements of herbaceous individual plants, as currently recommended for other plant groups (Chave et al. 2014).

Most importantly, we found that a single equation can reasonably be used to successfully predict the biomass of individual plants in different habitats for the large majority of the investigated species, at least within the range of environmental conditions investigated here, which was already wide (Table 2). A notable exception was the perennial ryegrass (Lolium perenne). It is possible that we sampled different selected ryegrass genotypes with contrasted ecophysiological and morphological characteristics since different varieties of ryegrass are used for hay production and pasture (Beecher et al. 2015). The strong site effect for this species may therefore have been confounded with a genotype effect. To our knowledge this study is the most comprehensive assessment of the transferability of biomass equations between different environments for herbaceous species. A few previous studies have compared allometric equations fitted for different disturbance regimes, including fire (van der Eynden 2011) and grazing (Tausch et al. 1994; Nafus et al. 2009, but all were within 
homogeneous abiotic conditions. Huenneke et al. (2001) and Andariese \& Covington (1986) compared different sites varying in abiotic conditions. The most frequent conclusion of these studies is that biomass equations should be calibrated for each investigated site. Only Huenneke et al. (2001) and our findings contrast with this prevailing view. Despite the good across-site transferability of the allometric equations evidenced in this study, further investigation is needed where both approaches would be specifically compared.

Based on these findings we recommend the application of this method for most herbaceous species, except for very small (below 0.05 meters height) and tall species (above 2 meters height) for which the proposed measurements may be unpractical. We furthermore suggest the following guidelines for interested users:

1- Potential users should fit their own equations rather than using the reported parameters for two reasons: i) to minimize potential observer biases, and ii) because prediction errors when extrapolating models to distinct biogeographic areas have not yet been evaluated.

2- Large environmental gradients should be sampled when calibrating the allometric equations and equations should be used within the range of investigated environmental conditions.

3- In order to determine the best equation for each species, all possible equations reported here should be fitted; the most appropriate species-specific equations cannot be selected a priori using basic knowledge of species architecture and size. As a default model, we recommend using a power model for a homogenous double cone which showed on average the best performances, all criteria combined.

This non-destructive, cross-site estimation method of individual plant biomass opens new perspectives for research at the individual and community levels. At the individual level, monitoring biomass trajectories of plant individuals will allow the assessment of changes in 
demographic rates in relation to environmental conditions. Such information can be used to better tease apart the respective influences of abiotic conditions and biotic neighbourhood in plant dynamics along their growth trajectories, and thus to enrich existing approaches based on biomass measurements at the end of a field experiment (e.g., Wilson \& Keddy 1986;

Goldberg et al. 1999; Freckleton \& Watkinson 2001). These empirical assessments may feed dynamical models of plant dynamics at the population and community levels (Lande et al. 2003; Rees \& Ellner 2009). With modern developments in theoretical ecology, dynamic modelling approaches have proved powerful in assessing the detailed nature of competition (Damgaard et al. 2002) and the importance of niche differentiation and fitness differences in the outcome of competition (Levine \& HilleRisLambers 2009; Adler et al. 2010; Kraft et al. 2015). Coexistence theory of herbaceous plants has mainly be applied in arid systems where parameters like reproductive output, survival, cover and density are monitored (Sears \& Chesson 2007; Adler et al. 2010; Kraft et al. 2015). The use of non-destructive estimates of individual biomass could help test this theory with models based on biomass production, which are more informative for systems like temperate grassland where population growth is mostly vegetative (Benson \& Hartnett 2006).

\section{Acknowledgement}

This study received financial support from the French Auvergne Région and FEDER. We thank Juliette Bloor and two anonymous reviewers for insightful comments on an early version of the manuscript.

\section{References}

Adler, P.B., Ellner, S.P. \& Levine, J.M. (2010). Coexistence of perennial plants: An embarrassment of niches. Ecology Letters, 13, 1019-1029. 
Andariese, S.W. \& Covington, W.W. (1986). Biomass Estimation for Four Common Grass Species in Northern Arizona Ponderosa Pine. Journal of Range Management, 39, 472473.

Assaeed, A. (1997). Estimation of biomass and utilization of three perennial range grasses in Saudi Arabia. Journal of arid Environments, 36, 103-111.

Barkaoui, K., Bernard-Verdier, M. \& Navas, M.L. (2013). Questioning the Reliability of the Point Intercept Method for Assessing Community Functional Structure in LowProductive and Highly Diverse Mediterranean Grasslands. Folia Geobotanica, 48, 393414.

Beecher, M., Hennessy, D., Boland, T.M., Mcevoy, M., O’Donovan, M. \& Lewis, E. (2015). The variation in morphology of perennial ryegrass cultivars throughout the grazing season and effects on organic matter digestibility. Grass and Forage Science, 70, 19-29.

Benson, E.J. \& Hartnett, D.C. (2006). The Role of Seed and Vegetative Reproduction in Plant Recruitment and Demography in Tallgrass Prairie. Plant Ecology, 187, 163-178.

Brathen, K.A. \& Hagberg, O. (2004). More efficient estimation of plant biomass. Journal of Vegetation Science, 15, 653-660.

Catchpole, W.R. \& Wheelert, C.J. (1992). Estimating plant biomass : A review of techniques. Australian Journal of Ecology, 17, 121-131.

Chave, J., Réjou-Méchain, M., Búrquez, A., Chidumayo, E., Colgan, M.S., Delitti, W.B.C., Duque, A., Eid, T., Fearnside, P.M., Goodman, R.C., Henry, M., Martínez-Yrízar, A., Mugasha, W.A., Muller-Landau, H.C., Mencuccini, M., Nelson, B.W., Ngomanda, A., Nogueira, E.M., Ortiz-Malavassi, E., Pélissier, R., Ploton, P., Ryan, C.M., Saldarriaga, J.G. \& Vieilledent, G. (2014). Improved allometric models to estimate the aboveground 
biomass of tropical trees. Global Change Biology, 20, 3177-3190.

407

408

409

410

411

412

413

414

415

416

417

418

419

420

421

422

423

424

425

426

427

428

Damgaard, C.F., Weiner, J. \& Nagashima, H. (2002). Modelling individual growth and competition in plant populations: growth curves of Chenopodium album at two densities. Journal of Ecology, 90, 666-671.

Enquist, B.J., Allen, A.P., Brown, J.H., Gillooly, J.F., Kerkhoff, A.J., Niklas, K.J., Price, C. a \& West, G.B. (2007). Biological scaling: does the exception prove the rule? Nature, $\mathbf{4 4 5 ,}$ E9-E10; discussion E10-E11.

Enquist, B.J. \& Niklas, K.J. (2002). Response to Sack et al. Global allocation rules for patterns in partioning. Science, 296, 4-5.

ESDB, V.. (2004). ESDB v2.0: The European Soil Database distribution version 2.0, European Commission and the European Soil Bureau Network, CD-ROM, EUR 19945 EN.

van der Eynden, M. (2011). Effects of fire history on species richness and carbon stocks in a Peruvian puna grassland, and development of allometric equations for biomass estimation of common puna species.

Freckleton, R.P. \& Watkinson, a. R. (2001). Asymmetric competition between plant species. Functional Ecology, 15, 615-623.

Goldberg, D.E., Rajaniemi, T.K., Gurevitch, J. \& Stewart-Oaten, A. (1999). Empirical approaches to quantifying interaction intensity: competition and facilitation along productivity gradients. Ecology, 80, 1118-1131.

Guevara, J.C., Gonnet, J.M. \& Estevez, O.R. (2002). Biomass estimation for native perennial grasses in the plain of Mendoza, Argentina. Journal of Arid Environments, 50, 613-619.

Gutierrez, J.R. \& Aguilera, L.E. (1989). Size-biomass relationships for some herbaceous 
plants of the Chilean arid region. Revista Chilena de Historia Natural, 62, 95-98.

430

431

432

433

434

435

Harmoney, K.R., Moore, K.J., George, J.R., Brummer, E.C. \& Russell, J.R. (1997).

Determination of Pasture Biomass Using Four Indirect Methods. Agron. J., 89, 665-672.

Harper, J.L. (1977). Population Biology of Plants. Academic Press.

Henry, M., Bombelli, A., Trotta, C., Alessandrini, A., Birigazzi, L., Sola, G., Vieilledent, G., Santenoise, P., Longuetaud, F., Valentini, R., Picard, N. \& Saint-André, L. (2013). GlobAllomeTree: International platform for tree allometric equations to support volume, biomass and carbon assessment. IForest, 6, 326-330.

Hirata, M., Oishi, K., Muramatu, K., Xiong, Y., Kaihotu, I., Nishiwaki, A., Ishida, J., Hirooka, H., Hanada, M., Toukura, Y. \& Hongo, A. (2007). Estimation of plant biomass and plant water mass through dimensional measurements of plant volume in the DundGovi Province, Mongolia. Grassland Science, 53, 217-225.

Hooper, D.U., Chapin, I.F.., Ewell, J.J., Hector, A., Inchausti, P., Lavorel, S., Lawton, J.H., Lodge, D.M., Loreau, M., Naeem, S., Scmid, B., Setälä, H., Symstad, A.J., Vandermeer, J. \& Wardle, D.A. (2005). Effects of biodiversity on ecosystem functioning: a consensus of current knowledge. Ecological Monographs, 75, 3-35.

Huenneke, L.F., Clason, D. \& Muldavin, E. (2001). Spatial heterogeneity in Chihuahuan Desert vegetation: implications for sampling methods in semi-arid ecosystems. Journal of Arid Environments, 47, 257-270.

Johnson, P., Johnson, C. \& West, N. (1988). Estimation of phytomass for ungrazed crested wheatgrass plants using allometric equations. Journal of Range Management, 41, 421425.

Kleyer, M., Bekker, R.M., Knevel, I.C., Bakker, J.P., Thompson, K., Sonnenschein, M., 
Poschlod, P., van Groenendael, J.M., Klimeš, L., Klimešová, J., Klotz, S., Rusch, G.M., Hermy, M., Adriaens, D., Boedeltje, G., Bossuyt, B., Dannemann, A., Endels, P., Götzenberger, L., Hodgson, J.G., Jackel, A.-K., Kühn, I., Kunzmann, D., Ozinga, W.A., Römermann, C., Stadler, M., Schlegelmilch, J., Steendam, H.J., Tackenberg, O., Wilmann, B., Cornelissen, J.H.C., Eriksson, O., Garnier, E. \& Peco, B. (2008). The LEDA Traitbase: a database of life-history traits of the Northwest European flora. Journal of Ecology, 96, 1266-1274.

Kraft, N.J.B., Godoy, O. \& Levine, J.M. (2015). Plant functional traits and the multidimensional nature of species coexistence. Procceding of the National Academy of Sciences, 112, 797-802.

Lande, R., Engen, S. \& Saether, B.E. (2003). Stochastic population dynamics in ecology and conservation. Oxford University Press.

Levine, J.M. \& HilleRisLambers, J. (2009). The importance of niches for the maintenance of species diversity. Nature, 461, 254-7.

Lohier, T., Jabot, F., Meziane, D., Shipley, B., Reich, P.B. \& Deffuant, G. (2014). Explaining ontogenetic shifts in root-shoot scaling with transient dynamics. Annals of botany, 114, 513-24.

Nafus, A.M., McClaran, M.P., Archer, S.R. \& Throop, H.L. (2009). Multispecies Allometric Models Predict Grass Biomass in Semidesert Rangeland. Rangeland Ecology \& Management, 62, 68-72.

Niklas, K.J. (2004). Plant allometry: is there a grand unifying theory? Biological reviews of the Cambridge Philosophical Society, 79, 871-89.

Peacock, J., Baker, T.R., Lewis, S.L., Lopez-Gonzalez, G. \& Phillips, O.L. (2007). The 
RAINFOR database: monitoring forest biomass and dynamics. Journal of Vegetation Science, 18, 535 .

Poorter, H., Jagodzinski, A.M., Ruiz-Peinado, R., Kuyah, S., Luo, Y., Oleksyn, J., Usoltsev, V. a., Buckley, T.N., Reich, P.B. \& Sack, L. (2015). How does biomass distribution change with size and differ among species? An analysis for 1200 plant species from five continents. New Phytologist, 208, 736-749.

Purves, D.W. \& Law, R. (2002). Fine-scale spatial structure in a grassland community: quantifying the plant' s-eye view. 121-129.

R Core Team. (2015). R: A Language and Environment for Statistical Computing.

Rees, M. \& Ellner, S.P. (2009). Integral projection models for populations in temporally environments varying. Ecological Monographs, 79, 575-594.

Röttgermann, M., Steinlein, T., Beyschlag, W. \& Dietz, H. (2000). Linear relationships between aboveground biomass and plant cover in low open herbaceous vegetation. Journal of Vegetation Science, 11, 145-148.

Sala, O.E., Parton, W.J., Joyce, L. a. \& Lauenroth, W.K. (1988). Primary production of the central grassland region of the United States. Ecology, 69, 40-45.

Sears, A.L.W. \& Chesson, P.L. (2007). New methods for quantifying the spatial storage effect: an illustration with desert annuals. Ecology, 88, 2240-7.

Shipley, B. \& Meziane, D. (2002). The balanced-growth hypothesis and the allometry of leaf and root biomass allocation. Functional Ecology, 16, 326-331.

Tackenberg, O. (2007). A new method for non-destructive measurement of biomass, growth rates, vertical biomass distribution and dry matter content based on digital image analysis. Annals of Botany, 99, 777-783. 
Tausch, Robin J., Robert S. Nowak, Allen D. Bruner, and J.S. (1994). Effects of simulated fall and early spring grazing on cheatgrass and perennial grass in western Nevada. Proceedings of Ecology and Management of Annual Rangelands. USDA Forest Service, Intermountain Research Station. Gen. Tech. Report INT-GTR-313, 113-119.

Weiner, J. (2004). Allocation, plasticity and allometry in plants. Perspectives in Plant Ecology, Evolution and Systematics, 6, 207-215.

Wilson, S.D. \& Keddy, P.A. (1986). Measuring diffuse competition along an environmental gradient: Results from a shoreline plant community. The American Naturalist, 127, 862869.

Zhang, L., Cui, G., Shen, W. \& Liu, X. (2016). Cover as a simple predictor of biomass for two shrubs in Tibet. Ecological Indicators, 64, 266-271. 